\title{
PENYELESAIAN KASUS PELANGGARAN HUKUM DI PERAIRAN NATUNA YANG DILAKUKAN OLEH KAPAL ASING VIETNAM DALAM PERSPEKTIF HUKUM LAUT INTERNASIONAL
}

\author{
Rahmawati Novia Sigit \\ Program Studi Magister Ilmu Hukum Universitas Andalas \\ Jl. Pancasila No.10 Kota Padang, 25118 \\ Email: Rahmawatinovia695@gmail.com
}

\begin{abstract}
The aim of this research for knowing and studying effort by Republic of Indonesia in settlement the illegal fishing as law deliquency case in Indonesia ocean by the vietnamese ship. The illegal fishing which no reported become make srious res for Indonesia, specially for vietnamese which know have number the most ship of fish thief in indonesia ocean. This case can settlement by any diplomacy by Indonesia, in between multilateral diplomacy, coercive diplomacy, and bilateral diplomacy, diplomacy efforts by Indonesia is the way for achieve national interest.
\end{abstract}

Keywords; Diplomacy, Illegal Fishing, Zona Ekonomi Eksklusif (ZEE).

\begin{abstract}
Abstrak
Penelitian ini bertujuan untuk mengetahui dan mengkaji upaya negara Indonesia dalam menyelesaikan kasus pelanggaran hukum di wilayah laut Indonesia yang melakukan kegiatan illegal fishing oleh kapal asing Vietnam. Penangkapan ikan secara ilegal, yang tidak dilaporkan menjadi masalah yang serius bagi Indonesia khususnya terhadap Vietnam yang diketahui memiliki jumlah kapal pencuri ikan ilegal terbanyak di Indonesia. Kasus ini dapat diselesaikan melalui berbagai macam diplomasi yang dilakukan oleh Indonesia diantaranya adalah diplomasi multilateral, diplomasi koersif, serta diplomasi bilateral. Upaya-upaya diplomasi yang dilakukan oleh Indonesia merupakan sebuah cara untuk mencapai kepentingan nasional.
\end{abstract}

Kata Kunci; Diplomasi, Illegal Fishing, Zona Ekonomi Eksklusif (ZEE).

\section{PENDAHULUAN}

Negara Kesatuan Republik Indonesia (NKRI) atau lebih umum disebut Indonesia, adalah negara yang terletak di kawasan Asia Tenggara yang dilintasi garis khatulistiwa dan berada di antara daratan benua Asia dan Australia, serta antara Samudra Pasifik dan Samudra Hindia. Indonesia adalah negara kepulauan terbesar di dunia yang terdiri dari 17.504 pulau. Dengan populasi Hampir 270.054.853 jiwa pada tahun 2018, Indonesia adalah negara berpenduduk terbesar 
keempat di dunia dan negara yang berpenduduk Muslim terbesar di dunia, dengan lebih dari 230 juta jiwa.

Semenjak berakhirnya Perang Dunia II, hukum laut yang merupakan cabang hukum internasional telah mengalami perubahan yang mendalam dan bahkan dapat dikatakan telah mengalami suatu revolusi sesuai dengan perkembangan dan tuntutan zaman. Dewasa ini menonjolnya peran hukum laut, bukan saja karena laut merupakan "jalan raya” yang menghubungkan suatu bangsa dengan bangsa yang lain ke seluruh pelosok dunia untuk segala macam kegiatan, bukan saja karena kekayaannya dengan segala macam jenis ikan yang vital bagi kehidupan manusia tetapi juga dan terutama karena kekayaan mineral yang terkandung di dasar laut itu sendiri. ${ }^{1}$

Secara historis laut memiliki dua fungsi penting: pertama, sebagai media komunikasi dan kedua sebagai gudang besar sumber daya, baik yang hidup maupun yang tak hidup. Kedua fungsi ini memicu berkembangnya aturan hukum. Prinsip dasar yang mengatur hukum laut adalah adalah bahwa "daratan mendominasi laut" sehingga situasi teritorial daratan menjadi titik awal penentuan hak maritim sebuah negara pantai. ${ }^{2}$

Negara-negara pantai mempunyai kedaulatan penuh di laut teritorialnya (termasuk dasar laut dan udara di atasnya) di sertai kewajiban untuk menjamin hak lintas damai bagi kapal-kapal asing. Indonesia merupakan salah satu negara yang memiliki banyak pantai mengingat status Indonesia sebagai negara kepulauan. Indonesia juga dikatakan sebagai negara yang memiliki kekayaan dan potensi sumber daya hayati yang besar. Potensi yang dimiliki Indonesia tersebut merupakan suatu peluang dan potensi ekonomi yang dapat dimanfaatkan untuk kemajuan perekonomian Indonesia, serta sebagai tulang punggung pembangunan nasional. Melimpahnya sumber daya perikanan di perairan laut Indonesia ternyata telah menarik perhatian pihak asing untuk juga dapat menikmatinya secara ilegal melalui kegiatan illegal fishing. ${ }^{3}$

${ }^{1}$ Dina Sunyowati dan Enny Narwati, Hukum Laut, Pusat Penerbitan dan Percetakan Unair (AUP), Surabaya, 2013, hlm. 1.

2 Malcolm N. Shaw QC, Hukum Internasional, Nusa Media, Bandung, 2013, hlm. 547.

3 Julianingsih Hehanussa, et.al., Penegakan Hukum Illegal Fishing Yang dilakukan Oleh Kapal Asing di Wilayah Laut Indonesia Di Tinjau Dari Hukum Laut Internasional, e-Journal Komunitas Yustisia Universitas Pendidikan Ganesha, Jurusan Ilmu Hukum, Volume 1 No. 2 Tahun 2018, hlm. 3. 
Dapat dikatakan sebagai illegal fishing jika kegiatan perikanan atau penangkapan ikan yang bertentangan dengan peraturan nasional yang berlaku atau kewajiban internasional, dilakukan oleh orang atau kapal asing suatu negara tanpa izin dari negara tempat penangkapan ikan terjadi, serta jika dilakukan oleh kapal yang mengibarkan bendera suatu negara yang menjadi anggota organisasi pengelolaan perikanan regional tetapi beroperasi tidak sesuai dengan ketentuan pelestarian dan pengelolaan yang diterapkan oleh organisasi tersebut atau ketentuan hukum internasional yang berlaku.

Illegal fishing adalah kegiatan perikanan yang tidak sah, kegiatan perikanan yang tidak diatur oleh peraturan yang berlaku, aktifitasnya tidak dilaporkan kepada suatu institusi atau lembaga perikanan yang tersedia/berwenang. Hal ini dapat terjadi di semua kegiatan perikanan tangkap tanpa tergantung kepada alat tangkap yang digunakan, lokasi, target species dan eksploitasi serta dapat muncul di semua tipe perikanan baik skala kecil dan industri, perikanan di zona jurisdiksi nasional maupun internasional.

Dalam hal ini penulis mengambil salah satu kasus yang terjadi pada 28 April 2019, merekam insiden saat kapal pengawas perikanan milik pemerintah Vietnam menabrak kapal perang Indonesia, KRI Tjiptadi 381. Kejadian bermula saat KRI Tjiptadi-381 melaksanakan Penegakan Hukum di ZEE Indonesia, tepatnya di Laut Natuna Utara, terhadap Kapal Ikan Asing (KIA) Vietnam BD 979 yang sedang melaksanakan Illegal Fishing (pencurian ikan) dan akan menangkap KIA Vietnam tersebut, namun KIA Vietnam tersebut dikawal oleh Kapal Pengawas Perikanan Vietnam, kapal pengawas perikanan Vietnam berusaha menghalangi proses penegakan hukum yang dilakukan oleh KRI Tjiptadi-381.

Dua kapal pengawas perikanan Vietnam KN 264 dan KN 231 telah dengan sengaja menabrakan diri ke KRI Tjiptadi-381 yang sedang membawa Kapal Ikan Asing (KIA) Vietnam BD 979 yang tertangkap melakukan pencurian ikan di perairan Indonesia khususnya wilayah utara perairan Natuna. Dari kejadian ini tidak saja merusak KRI Tjiptadi-381, bahkan KIA Vietnam BD 979 juga mengalami kebocoran hingga akhirnya tenggelam akibat ditabrak kapal pengawasan Vietnam tersebut. ${ }^{4}$

${ }^{4}$ https://regional.kompas.com/read/2019/04/29/08345151/2-kapal-pemerintah-vietnam-tabrak-kritjiptadi-381-yang-sedang-patroli, diakses pada Tanggal 16 November 2019, Pukul 11.40 WIB. 
Di insiden tersebut, 2 kapal pengawas perikanan Vietnam mengganggu proses penegakan hukum yang dilakukan KRI Tjiptadi-381. KN 264 dan KN 231 semula bermanuver dengan mendekati Kapal Ikan Asing Vietnam (KIAV) BD 979 dan beberapa kali menabraknya hingga bagian bakatnya rusak. KRI Tjiptadi tak menghiraukan manuver KN 264 dan KN 231 dengan tetap menggiring KIAV BD 979 ke Lanal Ranai. Namun, ternyata KN 264 lalu menabrak lambung kiri KRI Tjiptadi. Sedangkan KN 231 menabrak KIAV BD 979 hingga mengalami kebocoran dan tenggelam. Dua ABK KIAV BD 979 sempat melompat ke laut dan ditolong oleh kapal pengawas perikanan milik Vietnam. Meski demikian, KRI Tjiptadi-381 tetap bisa menangkap 12 anak buah kapal (ABK) KIAV BD 979. Selanjutnya ke-12 ABK Kapal Vietnam dibawa dan akan diserahkan ke Lanal Ranai guna proses hukum selanjutnya.

Dalam kasus ini Hukum Internasional yang dilanggar adalah International Regulations for Preventing Collisions at Sea (Peraturan Internasional untuk Mencegah Tabrakan di Laut) 1972 (COLREGs), dan International Convention for the Safety of Life at Sea (Konvensi Internasional untuk Keselamatan Kehidupan di Laut) 1974 (SOLAS).

Pada aturan Hukum Internasional terkait Peraturan Internasional untuk Mencegah Tabrakan di Laut 1972 (COLREGs) itu sendiri diterbitkan oleh Organisasi Maritim Internasional (IMO) dan menetapkan antara lain "aturan jalan" atau aturan navigasi yang harus diikuti oleh kapal dan kapal lainnya di laut untuk mencegah tabrakan antara dua atau lebih kapal. COLREGs juga dapat merujuk ke garis politik tertentu yang membagi saluran air pedalaman, yang tunduk pada aturan navigasi mereka sendiri dan saluran air pantai, yang tunduk pada aturan navigasi internasional. COLREGs berasal dari perjanjian multilateral yang disebut Konvensi Peraturan Internasional untuk Mencegah Tabrakan di Laut.

Meskipun aturan untuk menavigasi kapal ke daratan mungkin berbeda, aturan internasional menentukan bahwa mereka harus sedekat mungkin dengan aturan internasional. Di sebagian besar Eropa kontinental, Kode Européen des Voies de la Navigasi Intérieure (CEVNI, atau Kode Eropa untuk Navigasi di Perairan Darat) berlaku. Di Amerika Serikat, aturan untuk kapal yang menavigasi ke daratan diterbitkan bersamaan dengan aturan internasional. 
Sedangkan pada aturan lain yang terkait dengan pelanggaran hukum laut internasional lainnya adalah Konferensi SOLAS di tahun 1974 diadakan di markas IMO di London sejak 21 Oktober hingga 1 November, dan dihadiri oleh 71 negara. Menghasilkan konvensi SOLAS 1974 yang formatnya berlaku hingga saat ini. Selain berisi tentang persyaratan keselamatan, SOLAS 1974 juga menetapkan prosedur penerimaan terhadap sebuah perubahan (amandemen) atau disebut the tacit acceptance. Prosedur ini dirancang untuk memberi kepastian bahwa perubahan terhadap konvensi dapat dilakukan dan diterima dalam jangka waktu yang ditentukan. ${ }^{5}$

SOLAS adalah akronim dari Safety of Life At Sea, merupakan konvensi paling penting dari seluruh konvensi internasional tentang kemaritiman. SOLAS menjadi standar keselamatan maritim yang wajib diterapkan pada kapal niaga (merchant vessel) berukuran tertentu dan menjadi induk bagi terbitnya berbagai standar (code) bagi kontruksi kapal, peralatan, dan pengoperasian. ${ }^{6}$

Terkait dasar aturan yang dijadikan pedoman oleh KRI Tjiptadi-381 yang menahan diri dianggap sudah tepat berdasarkan hukum internasional, khususnya pada kasus Guyana v Suriname (dalam forum Arbitral Tribunal UNCLOS pada tahun 2004), penggunaan use of force hanya dapat dibenarkan jika memenuhi tiga syarat: tidak terhindarkan, kewajaran (reasonableness) dan keharus (necessity)."

Atas kasus pelanggaran ini masih perlu pendalaman lebih lanjut untuk memastikan hal tersebut. Karena kasus pelanggaran hukum yang dilakukan oleh kapal asing Vietnam tidak hanya melakukan kegiatan Illegal Fishing namun juga terjadinya pengklaiman kawasan ZEE yang dilakukan oleh kapal asing Vietnam. Bila demikian adanya, maka dua pihak sama-sama berhak melakukan patroli dan menghalangi penegakan hukum oleh negara lain.

Klaim-klaim sepihak yang dilakukan oleh negara-negara dunia ini disebabkan karena kurang jelasnya hukum laut internasional yang mengatur saat ini. Hukum laut tersebut adalah Konvensi Hukum Laut Perserikatan Bangsa-Bangsa Tahun 1958 dan 1960. Adanya permasalahan dan ketidakpastian mengenai hukum laut

5https://jurnalmaritim.com/solas-konvensi-internasional-keselamatan-pelayaran-yang-terinspirasi-tragedititanic/, diakses pada Tanggal 16 November 2019, Pukul 12.49 WIB.

${ }^{6}$ Ibid., 
tersebut menjadi dasar diselenggarakannya Konvensi Perserikatan Bangsa-Bangsa ketiga. Hasil dari adanya konvensi ini adalah lahirnya UNCLOS (United Nations Convention On The Law of The Sea) 1982 yang ditandatangani di Montego Bay, Jamaika, pada tanggal 10 Desember 1982. Pada konvensi Perserikatan BangsaBangsa ketiga ini, kemudian muncul wilayah perairan baru yaitu Zona Ekonomi Eksklusif (ZEE). ${ }^{7}$

Zona ini berkembang dari klaim-klaim sebelumnya yang belum tegas, terutama dengan kegiatan illegal fishing, dan sebagai perkembangan proses negosiasi yang berujung pada konvensi 1982. Ia menandai konsensi antara para pihak negara yang menghendaki laut teritorial 200 mil dan mereka yang menginginkan agar sistem kewenangan negara pantai lebih dibatasi.

Berdasarkan Pasal 56, negara pantai di zona ekonomi memiliki antara lain:

a. Hak berdaulat untuk tujuan eksplorasi dan eksploitasi, konservasi dan pengelolaan sumber daya alam, baik sumber hidup atau mati, dari perairan yang berada di atas dasar laut dan dasar lautnya dan lapisan dibawahnya dan berkenaan dengan kegiatan lain untuk eksploitasi dan ekplorasi ekonomi zona tersebut, seperti produksi energi dari air, arus laut dan angin;

b. Yurisdiksi terkait dengan (i) arsitektur dan penggunaan pulau, instalasi dan bangunan buatan; (ii) penelitian ilmiah kelautan, (iii) perlindungan dan pelestarian lingkungan laut.

Berdasarkan uraian latar belakang diatas, penulis akan mengkaji beberapa permasalahan yang akan dibahas untuk lebih lanjut dengan judul jurnal “Penyelesaian Kasus Pelanggaran Hukum Di Perairan Natuna Yang Dilakukan Oleh Kapal Asing Vietnam Dalam Perspektif Hukum Laut Internasional." Adapun permasalahan yang dapat diangkat dari judul tersebut, adalah:

1. Bagaimana penentuan garis batas ZEE antara pemerintah Republik Indonesia dan Pemenrintah Vietnam menurut ketentuan Hukum Laut Internasional?

2. Bagaimana upaya negara Republik Indonesia dalam menyelesaikan kasus pelanggaran hukum yang dilakukan oleh kapal asing Vietnam?

7 Maulidya Yuseini, et.al., Penyelesaian Sengketa Laut Antara Indonesia dan Malaysia di Wilayah Selat Malaka Menurut Hukum Laut Internasional, Lentera Hukum, Volume 5 Issue 3 (2018), pp, hlm. 458. 
Adapun tujuan penelitian yang hendak penulis capai dalam penelitian ini, yaitu Untuk mengetahui penentuan garis batas ZEE antara pemerintah Republik Indonesia dan Pemenrintah Vietnam menurut ketentuan Hukum Laut Internasional, dan untuk mengetahui upaya negara Republik Indonesia dalam menyelesaikan kasus pelanggaran hukum yang dilakukan oleh kapal asing Vietnam.

Diharapkan dari hasil penelitian ini dapat memberikan manfaat bagi mahasiswa ilmu hukum untuk dijadikan sebagai bahan referensi dan menambah wawasan tentang penentuan garis batas ZEE antara pemerintah Republik Indonesia dan Pemerintah Vietnam menurut ketentuan Hukum Laut Internasional dan upaya negara Republik Indonesia dalam menyelesaikan kasus pelanggaran hukum yang dilakukan oleh kapal asing Vietnam.

Dalam penelitian ini, dipergunakan tipe penelitian yuridis normatif yang artinya penelitian dilakukan dengan mendasarkan pada studi kepustakaan yaitu penelitian terhadap data skunder yang ada. Pendekatan yang digunakan dalam jurnal ini menggunakan dua cara pendekatan yaitu Statute Approach dan Conceptual Approach.

Statute Approach adalah Pendekatan undang-undang dilakukan dengan menelaah undang-undang dan regulasi yang bersangkut paut dengan isu hukum yang sedang ditangani. Pendekatan perundang-undangan dalam penelitian hukum normatif memiliki kegunaan baik secara praktis maupun akademis. Bagi penelitian untuk kegiatan praktis, pendekatan undang-undang ini akan membuka kesempatan bagi peneliti untuk mempelajari adakah konsistensi dan kesesuaian antara suatu undang-undang dengan undang-undang lainnya atau antara undang-undang dengan Undang-Undang Dasar atau regulasi dan undang-undang.

Sedangkan, Conceptual Approach yaitu Pendekatan konseptual dilakukan manakala peneliti tidak beranjak dari aturan hukum yang ada. Hal itu dilakukan karena memang belum atau tidak ada aturan hukum untuk masalah yang dihadapi. Oleh karena itulah yang ia harus membangun suatu konsep untuk dijadikan acuan di dalam penelitiannya. 


\section{PEMBAHASAN}

\subsection{Penentuan Garis Batas ZEE Antara Pemerintah Republik Indonesia dan Pemerintah Vietnam Menurut Ketentuan Hukum Laut Internasional.}

Dengan prinsip negara Kepulauan, Pemerintah Indonesia memasuki pelaksanaan Konferensi Hukum Laut Internasional III yang dimulai tahun 1971 dan berakhir di Montego Bay pada tahun 1982, melahirkan United Nations Convention on The Law of The Sea (UNCLOS) 1982. Negara Kepulauan menurut UNCLOS adalah suatu Negara yang seluruhnya terdiri dari satu atau lebih kepulauan dan dapat mencakup pulau-pulau lain (Pasal 46 ayat (1) Konvensi Hukum Laut 1982). ${ }^{8}$

Berdasarkan Konvensi Hukum Laut 1982 (UNCLOS), batas maritim suatu negara ditentukan oleh sebuah garis dasar (baseline). Dari beseline lah lebar laut territorial, ZEE, dan zona maritim lainnya diukur. Karena begitu pentingnya garis ini, di dalam UNCLOS diatur dengan rinci mekanisme penetapan baseline. Terdapat tiga jenis baseline, yaitu normal baseline, straight baseline dan archipelagic baseline. Penggunaannya bergantung pada kondisi geografis tiap negara. Menurut UNCLOS 1982, pengertian :

1. Pasal 46 butir (a) "Negara kepulauan" berarti suatu negara yang seluruhnya terdiri dari satu atau lebih kepulauan dan dapat mencakup pulau-pulau lain;

2. Pasal 46 butir (b) "kepulauan" berarti suatu gugusan pulau, termasuk bagian pulau, perairan di antaranya dan lain-lain wujud alamiah yang hubungannya satu sama lainnya demikian eratnya sehingga pulau-pulau, perairan di antaranya dan lain-lain wujud alamiah yang hubungannya satu sama lainnya demikian eratnya sehingga pulau-pulau, perairan dan wujud alamiah lainnya itu merupakan suatu kesatuan geografi, ekonomi dan politik yang hakiki, atau yang secara historis dianggap sebagai demikian.

3. Pasal 47 Butir (1) Garis pangkal kepulauan (archipelagic baselines) adalah garis pangkal lurus kepulauan yang menghubungkan titik-titik terluar pulaupulau dan karang kering terluar kepulauan itu, dengan ketentuan bahwa didalam garis pangkal demikian termasuk pulau-pulau utama dan suatu daerah dimana perbandingan antara daerah perairan dan daerah 
daratan, termasuk atol, adalah antara satu berbanding satu dan sembilan berbanding satu.

Kriteria ini sudah jelas dimiliki oleh negara Republik Indonesia dimana memiliki 17.504 pulau yang tersebar di 32 provinsi (sebelum terjadi pemekaran Kalimantan Utara dan Sulawesi Barat).

Wujud suatu Negara yang seluruhnya terdiri dari satu atau lebih kepulauan dan dapat mencakup pulau-pulau lain (Pasal 46 ayat (1) Konvensi Hukum Laut 1982). Wujud suatu Negara Kepulauan ditentukan berdasarkan penentuan garis pangkal lurus kepulauan archipelagic straight baseline sebagaimana ditegaskan dalam Pasal 47 ayat (1) Konvensi Hukum Laut 1982 bahwa "Suatu Negara Kepulauan dapat menarik garis pangkal lurus kepulauan yang menghubungkan titik terluar kepulauan itu, dengan ketentuan bahwa di dalam garis pangkal demikian termasuk pulau-pulau utama dan suatu daerah dimana perbadingan antara daerah perairan dan daerah daratan, termasuk atol, adalah antara satu berbanding satu dan sembilan berbanding satu". ${ }^{9}$ Sedangkan Straight baseline diperuntukkan bagi bagi negara yang kontur pantainya berbentuk "zig-zag" atau terdapat banyak sekali pulau-pulau di sepanjang pantainya.

Sedangkan normal baseline terdapat pada Pasal 7 mengadopsi dan menambah dua persyaratan pengukuran metode Garis Pangkal Lurus yang dapat digunakan oleh suatu negara. Penarikan batas laut teritorial dengan cara penarikan garis pangkal lurus, merupakan garis pangkal yang ditarik dengan menghubungkan titiktitik terluar dengan menggunakan garis lurus. Hal ini bisa dilakukan dengan memenuhi beberapa kriteria yang tercantum pada Konvensi Teritorial 1958 (KLT) yang kemudian diadopsi dalam UNCLOS.

Syarat pertama adalah jika kontur pantai berbentuk "zig-zag" (deeply intended or cut into) atau berpulau (fringe of island) di sepanjang bibir pantainya dalam jarak yang dekat (immediate vicinity). Berikutnya adalah arah straight baseline yang harus sejajar dengan kontur pantai (should not depart from the general direction of the coast); dan air yang diapit oleh pantai dan straight baseline harus memiliki hubungan dekat yang sedemikian hingga (closely linked to) dengan negara dimaksud. Di dalam kasus ini, bibir pantai Vietnam yang menghadap Indonesia

\footnotetext{
9 Johanis Leatemia, Op. Cit., hlm. 8.
} 
tidak memiliki kontur "zig-zag" atau berpulau. Kita dapat menggunakan kondisi bibir pantai Norwegia yang menghadap Norwegian Sea sebagai perbandingan. Dengan demikian penggunaan straight baseline oleh Vietnam bertentangan dengan KLT dan UNCLOS.

Setiap negara kepulauan akan mempergunakan garis pangkal lurus kepulauan (straitgh baselines) sebagai garis pangkal untuk menetapkan zona-zona maritimnya seperti laut teritorial, zona tambahan, landas kontinen dan zona ekonomi eksklusif. Walaupun tidak tertutup kemungkinan suatu negara kepulauan juga akan mempergunakan garis pangkal normal dan garis pangkal lurus pada bagian-bagian pantai yang sesuai untuk diterapkannya garis pangkal-garis pangkal tersebut. ${ }^{10}$

Selanjutnya jarak dari daratan ke beberapa pulau terluar Vietnam sebagai salah satu titik garis straight baseline-nya, ada yang mencapai 74,2 mil (119 km). Tidak ada justifikasi untuk mengatakan bahwa pulau yang jauhnya demikian memenuhi kriteria immediate vicinity. Tidak rasional pula mengatakan bahwa garis yang ditarik ke pulau yang 74,2 mil jauhnya dari daratan itu "sejajar" dengan arah bibir pantai; juga untuk mengatakan bahwa perairan yang sedemikian jauhnya closely linked to Vietnam.

Gambar I. Kondisi Pantai Vietnam

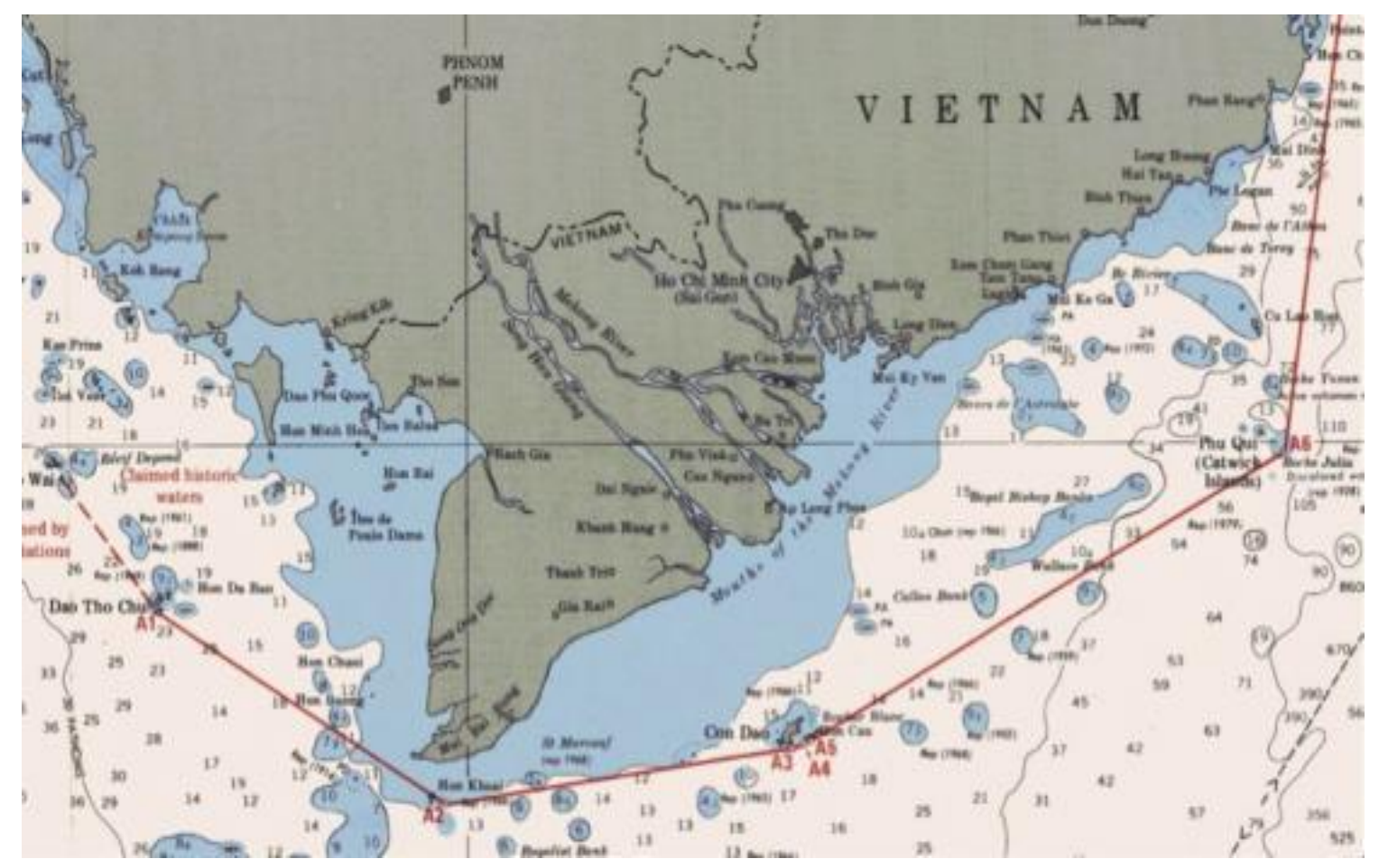

10 Magdariza dan Ferdi, Pengantar Hukum Laut, Andalas University Press, Padang, 2012, hlm. 43. 
Gambar 2. Kondisi Pantai Norwegia

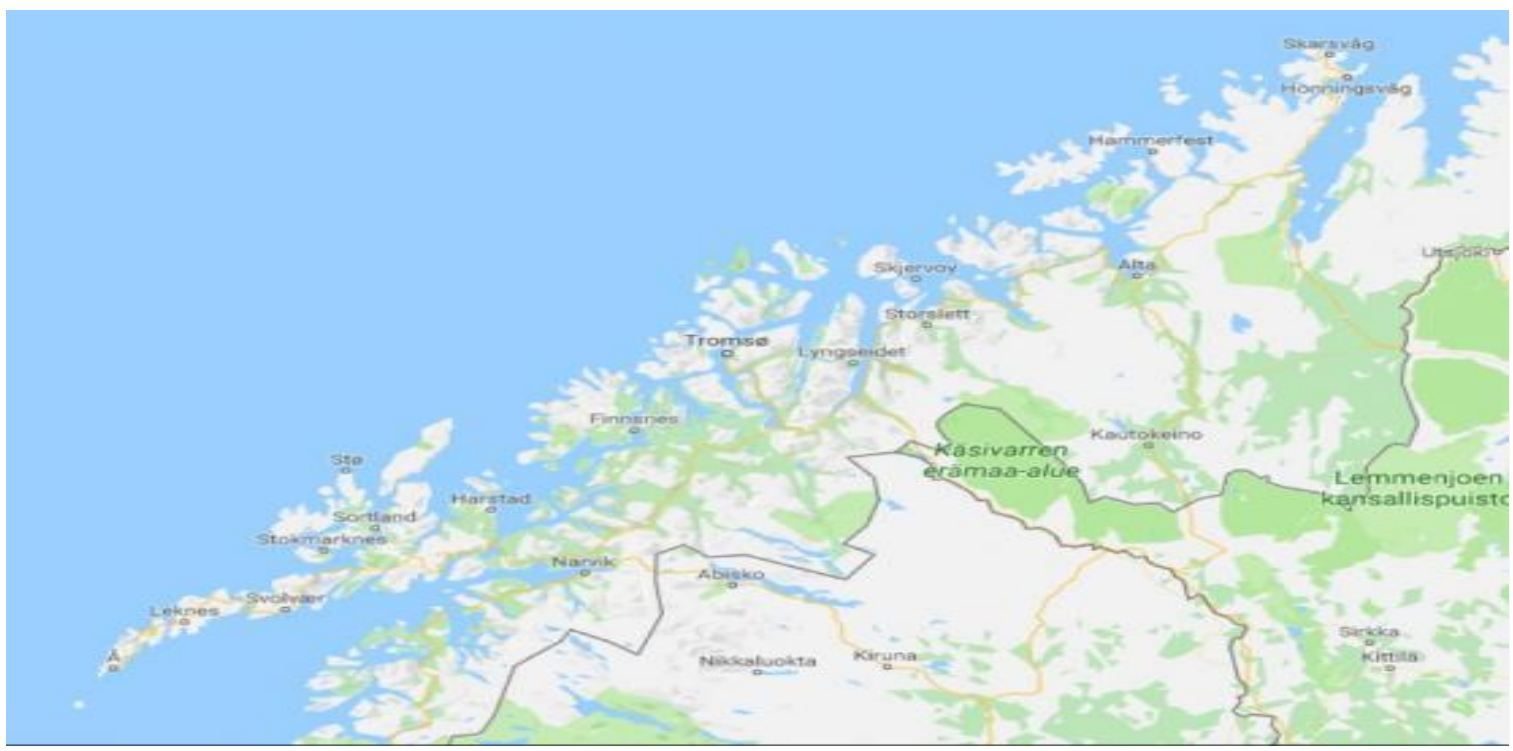

Ada 2 implikasi dari penggunaan garis yang tidak sesuai dengam KLT dan UNCLOS. Pertama, wilayah perairan yang berada di antara bibir pantai Vietnam dan pulau-pulau tersebut berstatus sebagai perairan pedalaman. Padahal menurut UNCLOS perairan tersebut seharusnya sebagian adalah laut territorial Vietnam dan ZEE Vietnam. Dalam konteks kebebasan berlayar dan pengelolaan sumber daya, perubahan ini merupakan hal yang cukup signifikan. Kedua, straight baseline Vietnam tersebut "mendorong" batas terluar ZEE Vietnam semakin mendekati Indonesia.

Gambar 3. Ilustrasi Batas Terluar ZEE Vietnam

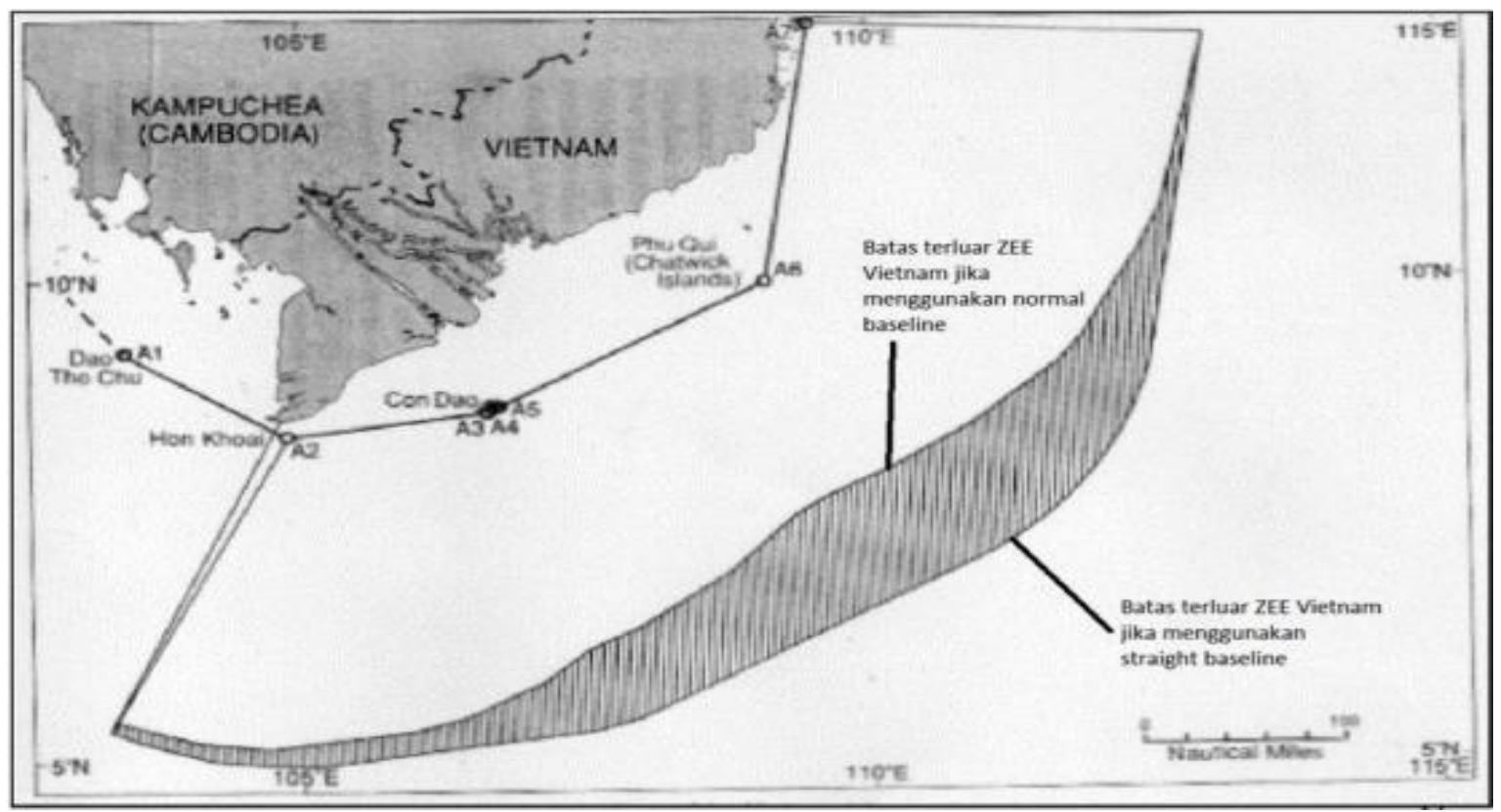


Sudah tentu batas terluar ZEE Vietnam pada akhirnya semakin dekat dengan Indonesia, dan berdampak pada luasan area tumpang tindih ZEE Indonesia dan Vietnam. Dalam konteks delimitasi, hadirnya aktivitas negara dalam sebuah wilayah perairan merupakan hal yang penting. Vietnam Coast Guard dan kapal perikanan Vietnam menjadi begitu aktif dalam kondisi ini karena Vietnam ingin hasil perundingan garis batas ZEE Indonesia-Vietnam adalah garis yang sama dengan batas landas kontinen Indonesia-Vietnam (Single line).

Penting untuk dicatat bahwa posisi garis landas kontinen Indonesia-Vietnam berada lebih dekat ke Indonesia dibandingkan dengan proposal garis batas ZEE yang diajukan oleh Indonesia. Untuk memudahkan pemahaman ini dapat diamati pada gambar di bawah yang menampilkan visual dari tumpang tindih klaim ZEE Indonesia.

Gambar 4. Ilustrasi Batas Terluar ZEE Indonesia Dan Vietnam, Proposal Garis Batas ZEE Dari Indonesia Dan Vietnam.

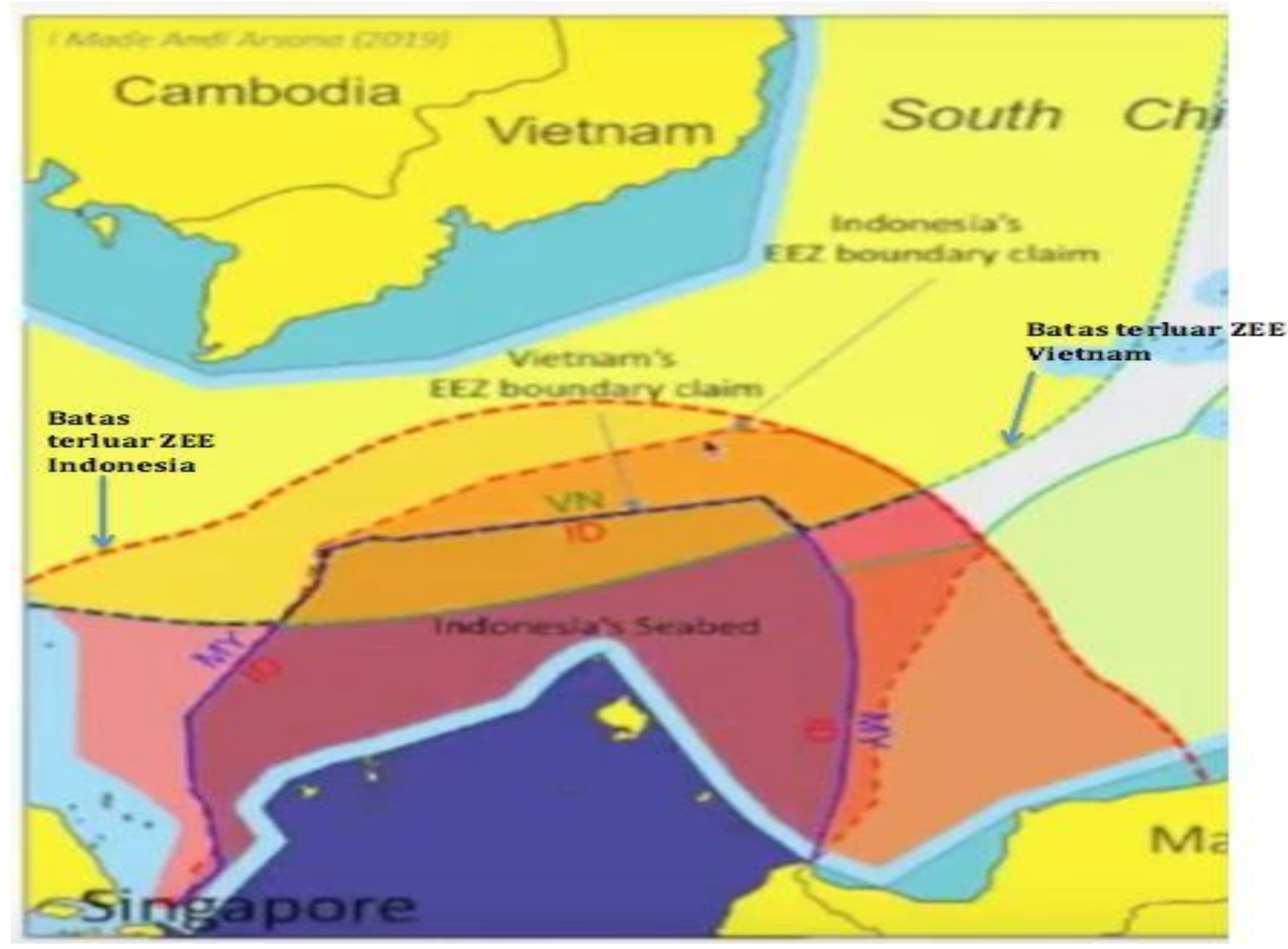

Dari gambar di atas, yang dimaksud dengan "Indonesia's EZZ Boundary Claim" adalah proposal garis batas ZEE dari Indonesia; dan yang dimaksud dengan 
“Vietnam's EZZ Boundary Claim” adalah proposal garis proposal garis batas ZEE dari Vietnam.

\subsection{Upaya Negara Republik Indonesia Dalam Menyelesaikan Kasus Pelanggaran Hukum Yang Dilakukan Oleh Kapal Asing Vietnam.}

Rezim ZEE memberikan negara pantai suatu "hak berdaulat" (sovereign rights) atas eksplorasi dan ekploitasi sumber daya alam dan aktivitas terkait lainnya di ZEE. Sebagai pertimbangannya UNCLOS 1982 juga memberikan hak kepada maritime user states untuk tetap dapat melaksanakan kebebasan penerbangan serta peletakan pipa-pipa dibawah dan kabel bawah laut. Hal ini merupakan upaya UNCLOS 1982 yang berusaha untuk mengakomodasi konflik kepentingan antar dua kelompok negara. Ketakutan user maritime states ZEE, dikompensasi dengan diberlakukannya rezim laut bebas pada ZEE yang berkenaan dengan freedom of navigation. ZEE diakui sebagai zona maritim tersendiri yang mempunyai karakternsui generis, yang meliputi 3 prinsip yaitu: ${ }^{11}$

1. Diaturnya hak dan kewajiban Negara pantai

2. Diaturnya hak dan kewajiban Negara lain, serta

3. Diaturnya aktivitas-aktivitas lain di ZEE yang tidak termasuk dalam kategori yang disebutkan pada pion 1 dan dan 2 .

UNCLOS 1982 secara garis besar membedakan wilayah laut menjadi dua kategori wilayah laut dimana negara dapat menegakan hukumnya terhadap IUU Fishing, yaitu wilayah laut yang berada di bawah kedaulatan dan wilayah laut dimana suatu negara memiliki yurisdiksi. Kawasan laut yang tunduk di bawah kedaulatan suatu negara pantai/kepulauan adalah perairan pedalaman dan laut teritorial atau perairan kepulauan dan laut teritorial. Sedangkan kawasan laut dimana suatu negara pantai/kepulauan memiliki hak berdaulat dan yurisdiksi adalah ZEE dan Landas Kontinen. Wilayah ZEE mempunyai status hukum yang sui generis (unik/berbeda). Keunikan tersebut terletak pada eksistensi hak dan kewajiban negara pantai dan negara lain atas ZEE. Berbeda dengan di laut teritorial, dimana negara pantai mempunyai kedaulatan, di ZEE negara pantai hanya mempunyai hak berdaulat. Hak berdaulat tersebut terbatas pada eksplorasi dan

11 Dhiana Puspitawati, Hukum Laut Internasional, Kencana, Depok, 2017, hlm.71-72. 
eksploitasi sumber daya kelautan baik sumber daya hayati maupun non-hayati. ${ }^{12}$ Potensi laut Indonesia begitu menguntungkan bagi nelayan Indonesia. Namun, sering kali Indonesia dibuat geram dengan datangnya kapal asing masuk ke wilayah perairan Nusantara. Kapal asing kerap menganggap posisi kapal masih berada di landasan kontinen. Padahal, kawasan perairan Natuna termasuk ke Zona Ekonomi Eksklusif (ZEE) Indonesia.

Direktorat Polisi Air dan Udara Barhakam Polri mendapati 952 kasus di perairan Indonesia sejak Januari hingga November 2018. Kasus terbanyak merupakan illegal fishing. Dirpolair Korpolairud Barhakam Polri Brigjen Lotharia Latif mengatakan illegal fishing masih menjadi permasalahan teratas di perairan Indonesia. Tercatat ada sebanyak 376 kasus yang 17 di antaranya merupakan kapal ikan asing."Yang masih menjadi berita hangat adalah illegal fishing di perairan Indonesia, itu jumlah yang kita laksanakan dalam rangka penegakan hukum ada 376 kasus di mana kapal ikan Indonesia ada 359 dan kapal ikan asing 17 kasus," ujarnya saat jumpa pers di Markas Ditpolair Barhakam Polri, Tanjung Priok, Jakarta Utara, Jumat (30/11/2018). Latif merinci, dari 17 kapal ikan asing, 12 di antaranya kapal berbendera Vietnam yang melakukan illegal fishing di Perairan Natuna. Lalu, 5 kapal lain berasal dari Malaysia. ${ }^{13}$ "Kemudian wilayah penegakan kapal ikan asing yang paling tinggi ada di Perairan Natuna yaitu 12 kasus, memang ini relevan karena berbatasan dengan wilayah perbatasan. Terus sisanya kapal Malaysia yang tertangkap di wilayah Aceh, Perairan Sumatera Utara, Perairan Riau, dan Perairan Kaltim," ucapnya. Kasus lainnya yang tercatat ialah penggunaan bahan peledak 110 kasus, pencurian 62 kasus, perlindungan pekerja imigran Indonesia 6 kasus, migas 47 kasus, illegal logging 44 kasus, illegal minning 21 kasus, penyelundupan 12 kasus, kepabeanan 16 kasus, dan perompakan 14 kasus. $^{14}$

Diplomasi maritim Indonesia dalam upaya pemberantasan illegal fishing yang terjadi di perairan Indonesia tidak hanya didukung oleh objek hukum internasional, tetapi juga diperkuat melalui kebijakan dan peraturan domestik mengenai hukum kelautan dan perikanan. Beberapa kebijakan dan peraturan tersebut diantaranya

\footnotetext{
12 Usmawadi Amir, Penegakan Hukum IUU Fishing Menurut UNCLOS 1982 (Studi Kasus: Volga Case), Jurnal Opinio, Vol 12 Januari-April 2013, hlm. 72.

${ }_{13}$ https://news.detik.com/berita/d-4324943/baharkam-tangani-952-kasus-perairan-selama-2018, diakses pada Tanggal 19 November 2019, Pukul 06.32 WIB.

14 Ibid.
} 
adalah pembentukan Satgas IUU Fishing dan kebijakan pembakaran dan penenggelaman kapal-kapal yang telah disita pengadilan dan kasusnya telah dinyatakan inkracht atau terbukti melakukan IUU Fishing, mengadakan moratorium atau penghentian sementara izin bagi kapal eks-asing, dan pelarangan penggunaan alat tangkap ikan yang berbahaya sepeti trawl atau pukat harimau. Mengenai upaya pemberantasan IUU Fishing yang secara khusus dapat diimplementasikan di perairan Natuna dapat dilakukan melalui penerapan beberapa kebijakan, diantaranya relokasi nelayan.

Dengan adanya peningkatan jumlah nelayan lokal yang beroperasi hingga ke ZEEI perairan Kepulauan Natuna dapat menekan praktik illegal fishing karena kelompok masyarakat yang terdiri dari nelayan tersrebut juga berfungsi sebagai kelompok masyarakat pengawas (Pokmaswas). Namun demikian, yang harus menjadi catatan penting adalah upaya ini harus diperkuat melalui diplomasi bendera, yang artinya seluruh kapal-kapal nelayan yang melakukan operasi perikanan wajib memasang bendera Indonesia sebagai simbol eksistensi negara. Kebijakan domestik yang juga dinilai akan mempengaruhi penguatan diplomasi maritim Indonesia dalam memberantas illegal fishing juga ditunjukkan melalui inisiatif pemerintah untuk menjadikan Natuna sebagai pusat pelelangan ikan regional. Sektor perikanan di Natuna ingin dikembangkan melalui pembangunan infrastruktur dan cold storage sebagai ruang penyimpanan bagi ikan-ikan yang telah ditangkap. Dengan demikian program tersebut dapat mendukung dan membuka kesempatan bagi pengusaha perikanan dan nelayan lokal untuk meningkatkan kapasitas produksi perikanannya, dan menekan jumlah penangkapan ikan oleh pihak asing.

Menurut Pasal 3 ayat 1 bahwa apabila ZEEI tumpang tindih dengan zona ekonomi eksklusif negara-negara yang pantainya saling berhadapan atau berdampingan dengan Indonesia, maka penetapan batas diselesaikan melalui persetujuan. Dalam ayat 2 dinyatakan bahwa apabila persetujuan tersebut belum dicapai dan tidak ada keadaan-keadaan khusus yang perlu dipertimbangkan, maka garis batas zona ekonomi eksklusif tersebut adalah garis tengah atau garis sama jarak antara garis-garis pangkal laut teritorial atau titik-titik terluar Indonesia dan garis-garis pangkal laut teritorial atau titik-titik terluar negara tersebut. Ketentuan 
Pasal 3 ini sesuai dengan Pasal 74 tentang penetapan garis batas zona eksklusif antara dua negara yang letak pantainya berhadapan maupun berdampingan melalui persetujuan atas dasar hukum internasional. ${ }^{15}$

Secara umum, diplomasi merupakan manajemen dalam hubungan antar negara yang dilakukan oleh suatu negara untuk mencapai kepentingan nasional sebagai pelaksanaan dari politik luar negerinya. Konsep diplomasi kemudian mengalami perluasan, baik dalam hal isu maupun aktor, yang selanjutnya melahirkan berbagai bentuk dan jenis diplomasi, salah satunya adalah diplomasi maritim (maritime diplomacy). Secara sederhana, diplomasi maritim merupakan manajemen hubungan antar negara melalui domain maritim. Menurut Miere, diplomasi maritim tidak hanya berarti penggunaan diplomasi untuk mengelola konflik dan ketegangan antar negara terkait permasalahan maritim melalui penyusunan instrumen hukum internasional. Tetapi diplomasi maritim juga merupakan penggunaan aset atau sumber daya dalam domain maritim untuk mengatur hubungan antar negara. Jika umumnya diplomasi melibatkan diplomat sebagai representasi negara, diplomasi maritim tidak hanya melibatkan policy maker (aktor negara). Diplomasi maritim dapat melibatkan analis dan akademisi untuk mengkaji mengenai tren dan perkembangan yang terjadi dalam hubungan internasional dan keamanan global.

Diplomasi maritim dikategorikan menjadi tiga tipologi, yaitu cooperative maritime diplomacy, persuasive maritime diplomacy, dan coercive maritime diplomacy, dimana aktor utamanya ialah maritime forces dan pemerintah. Berdasarkan perspektif Indonesia, diplomasi maritim oleh maritime forces yang dapat beroperasi di ZEEI diperankan oleh TNI AL yang dibantu oleh TNI AU, dan Bakamla. Diplomasi maritim TNI AL dan Bakamla dalam bentuk cooperative maritime diplomacy misalnya kerja sama patroli bersama. Namun demikian upaya tersebut belum dapat dilaksanakan di ZEEI perairan Kepulauan Natuna oleh karena faktor kepentingan politik kedua negara berbeda.

Diplomasi Maritim Kooperatif Diplomasi Maritim Indonesia dalam upaya mewujudkan visi sebagai PMD dilakukan melalui upaya kerja sama guna menyelesaikan berbagai permasalahan terkait kemaritiman dengan negara-negara

15 Dikdik Mohamad Sodik, Hukum Laut Internasional dan Pengaturannya di Indonesia, PT Refika Aditama, PT Refika Aditama, Bandung, 2014, hlm. 99. 
tetangga, seperti masalah batas maritim maupun batas ZEE. Upaya diplomasi maritim yang bersifat kooperatif ini dapat dilihat dari usaha Indonesia mendorong pembentukan berbagai forum kerja sama dan kesepakatan bilateral maupun trilateral dengan negara lain di kawasan. Menurut Kementerian Luar Negeri, "forum kerja sama kemaritiman merupakan lembaga, badan, atau wadah antar negara yang dibentuk untuk mengedepankan kerja sama dalam bidang kemaritiman antara lain bidang keamanan dan keselamatan laut, pengelolaan sumber daya kelautan dan pengelolaan perbatasan."

Diplomasi Maritim Persuasif Selain upaya kooperatif, diplomasi maritim Indonesia juga diimplementasikan melalui upaya persuasif. Upaya persuasif ini dimaknai sebagai tindakan Indonesia yang berusaha mendorong pengakuan negara lain terhadap kontribusi dan kepemimpinan Indonesia dalam urusan kemaritiman.Upaya persuasif dalam diplomasi maritim Indonesia juga dilakukan Indonesia dengan mengambil peran penting dalam kepemimpinan di ASEAN. Upaya tersebut dapat dilihat sebagai usaha pemerintah untuk menunjukkan wibawa, yang selanjutnya dapat menjadi sarana persuasi terhadap negara lain dalam pencapaian kepentingan nasional di bidang maritim.

Diplomasi Maritim Koersif Selain dua bentuk diplomasi maritim yang dipaparkan di atas, upaya diplomasi maritim Indonesia juga ditunjukkan melalui cara-cara koersif. Cara koersif itu ditunjukkan melalui tindakan tegas penegakan hukum melalui kebijakan membakar dan menenggelamkan kapal-kapal asing yang melakukan aktivitas penangkapan ikan secara ilegal di wilayah perairan Indonesia. Berdasarkan laporan Kementerian Kelautan dan Perikanan (KKP), sepanjang tahun 2015 penindakan hukum yang dilakukan oleh KKP berupa penenggelaman kapal, pemeriksaan, pemulangan anak buah kapal (ABK), dan penangkapan terhadap kapal ilegal. Pemerintah telah menenggelamkan sebanyak 113 kapal ilegal berbagai negara seperti Malaysia, Filipina, Vietnam, Thailand, Papua Nugini, Tiongkok, Panama, dan lainnya; memeriksa 23.041 kapal; memulangkan ABK asing sebanyak 1.020 orang atas kasus perbudakan; serta menangkap 157 unit kapal ilegal sepanjang tahun 2015 (Kementerian Kelautan dan Perikanan 2016). Kemudian pada tahun 2016, penindakan hukum berupa proses lebih lanjut oleh aparat 
dilakukan terhadap 136 unit kapal dari 149 unit kapal ikan asing yang melakukan pelanggaran illegal fishing (Kementerian Kelautan dan Perikanan 2017).

Hingga Maret 2017, pemerintah melalui Satuan Tugas (Satgas) 511 telah menenggelamkan 317 kapal asing. Satgas 511 sendiri adalah kerja sama multi instansi antara Kementerian Kelautan dan Perikanan, TNI Angkatan Laut, Kepolisian RI, dan Kejaksaan Agung untuk pemberantasan illegal fishing. Satgas ini dibentuk melalui Peraturan Presiden Nomor 115 tahun 2015 (Yakti and Susanto 2017). Selain itu, pemerintah Indonesia juga secara aktif melakukan pengawasan melalui Operasi Kapal Pengawas di Wilayah Pengelolaan Perikanan Negara Republik Indonesia (WWP-NRI) dengan rata-rata hari operasi sebanyak 277 hari layar di wilayah barat dan di wilayah timur sebanyak 257 hari layar. Tujuan pengawasan tersebut adalah dalam rangka mengawasi sumber daya kelautan dan perikanan di seluruh WWP-NRI (Kementerian Kelautan dan Perikanan 2016). Hasilnya adalah, sepanjang tahun 2016, sebanyak 149 kapal ikan asing dihentikan dan diperiksa serta 140 kapal ditahan oleh kapal pengawas (Kementerian Kelautan dan Perikanan 2017). Smart Maritime Diplomacy Paparan di atas menunjukkan bahwa pemerintah Indonesia mengupayakan diplomasi maritim dengan beragam cara. Hal itu menegaskan bahwa ide besar PMD benar-benar berusaha diwujudkan.

Adapun cara yang dilakukan Indonesia, sebagaimana temuan penelitian ini, adalah dengan mengintegrasikan tiga bentuk diplomasi maritim sebagaimana yang dikemukakan oleh Miere. Pertama, cara kooperatif yang dilakukan melalui diplomasi untuk mendorong kerja sama secara bilateral dengan Vietnam dengan tujuan untuk menyelesaikan masalah batas maritim dan tumpang tindih ZEE yang diwujudkan melalui melalui pertemuan teknis dan pertemuan kolaboratif dengan Malaysia dan Vietnam; Kedua, diplomasi maritim dalam bentuk persuasif dilakukan untuk memperoleh dan meningkatkan pengakuan negara lain terhadap wibawa kedaulatan maritim Indonesia. Tiga bentuk diplomasi maritim yang dilakukan oleh Indonesia menunjukkan bahwa pemerintah mengintegrasikan cara-cara soft maritime diplomacy (koorperatif dan persuasif) dan hard maritime diplomacy (koersif). Jika hard maritim diplomacy dilakukan Indonesia sebagai penegasan independensi negara untuk menjaga kedaulatan maritimnya dari segala bentuk ancaman, maka soft maritime diplomacy menuntut Indonesia untuk secara aktif 
mendorong kerja sama dan kolaborasi sinergis dengan berbagai aktor. khususnya di level kawasan Asia Tenggara dan organisasi regional ASEAN. Dalam kasus ini Kementerian Kelautan dan Perikanan memutuskan menyelesaikan insiden penangkapan kapal di Natuna yang berujung pada ditangkapnya salah satu pengawas perikanan asal Indonesia oleh pihak Vietnam, Minggu (21/5) kemarin, dengan jalan diplomatik. Sekretaris Jendral Kementerian Kelautan dan Perikanan (KKP) Rifky Effendi Hardijanto menyebut, kedua negara telah sepakat menyelesaikan insiden Natuna yang terjadi di kawasan Zona Ekonomi Ekslusif (ZEE) secara diplomatik dan tidak berlarut-larut.

\section{SIMPULAN}

Dalam mengelola hubungan diplomatiknya terkait permasalah illegal fishing, pemerintah Indonesia memanfaatkan instrumen diplomasi maritim yang diperankan oleh maritime forces Indonesia dan unsur pemerintah. Diplomasi maritim Indonesia dapat diimplementasikan melalui mekanisme forum di tingkat bilateral, regional maupun global. Diplomasi batas maritim dengan Vietnam untuk menetapkan batas ZEEnya dengan Indonesia juga menjadi strategi penting yang harus diprioritaskan oleh pemerintah untuk memperkuat posisi dan klaim ZEEI di perairan Kepulauan Natuna. Adapun pada tingkat domestik upaya pemberantasan IUU Fishing dilakukan pemerintah melalui penerapan kebijakan hukuman pembakaran dan penenggelaman kapal, mengadakan moratorium, pelarangan penggunaan alat tangkap ikan yang berbahaya, dan pengembangan infrastruktur perikanan di Natuna.

\section{DAFTAR PUSTAKA}

\section{Buku}

Dhiana Puspitawati, Hukum Laut Internasional, Kencana, Depok, 2017.

Dikdik Mohamad Sodik, Hukum Laut Internasional dan Pengaturannya di Indonesia, PT Refika Aditama, PT Refika Aditama, Bandung, 2014.

Dina Sunyowati dan Enny Narwati, Hukum Laut, Pusat Penerbitan dan Percetakan Unair $\quad$ (AUP), $\quad$ Surabaya, 2013. 
I Made Pasek Diantha, Metodologi Penelitian Hukum Normatif, Prenada Media Group, Jakarta, 2017.

Malcolm N. Shaw QC, Hukum Internasional, Nusa Media, Bandung, 2013.

Magdariza dan Ferdi, Pengantar Hukum Laut, Andalas University Press, Padang, 2012.

Johanis Leatemia, Pengaturan Hukum Daerah Kepulauan, CV Budi Utama, Yogyakarta, 2019.

Suteki dan Galang Taufani, Metodologi Penelitian Hukum (Filsafat, Teori dan Praktik), Rajawali Pers, Depok, 2018.

\section{Jurnal}

Maulidya Yuseini, et.al., Penyelesaian Sengketa Laut Antara Indonesia dan Malaysia di Wilayah Selat Malaka Menurut Hukum Laut Internasional, Lentera Hukum, Volume 5 Issue 3 (2018).

Julianingsih Hehanussa, et.al., Penegakan Hukum Illegal Fishing Yang dilakukan Oleh Kapal Asing di Wilayah Laut Indonesia Di Tinjau Dari Hukum Laut Internasional, e-Journal Komunitas Yustisia Universitas Pendidikan Ganesha, Jurusan Ilmu Hukum, Volume 1 No. 2 Tahun 2018.

Usmawadi Amir, Penegakan Hukum IUU Fishing Menurut UNCLOS 1982 (Studi Kasus: Volga Case), Jurnal Opinio, Vol 12 Januari-April 2013.

\section{Peraturan Perundang-Undangan \& Perjanjian Internasional}

International Regulations for Preventing Collisions at Sea 1972 (COLREGs).

International Convention for the Safety of Life at Sea 1974 (SOLAS).

United Nations Convention on The Law of The Sea (UNCLOS) 1982.

Undang-Undang Nomor 5 Tahun 1983.

Zona Ekonomi Eksklusif (ZEEI) Indonesia.

\section{Website}

https://regional.kompas.com/read/2019/04/29/08345151/2-kapal-pemerintahvietnam-tabrak-kri-tjiptadi-381-yang-sedang-patroli

https://jurnalmaritim.com/solas-konvensi-internasional-keselamatan-pelaya ran-yang-terinspirasi-tragedi-titanic/

https://news.detik.com/berita/d-4324943/baharkam-tangani-952-kasus-per airan-selama-2018 